\title{
Managing in ethnic Chinese communities: Culture, institutions, and context
}

\author{
David Ahlstrom • Shyh-jer Chen • Kuang S. Yeh
}

Published online: 7 July 2010

(C) Springer Science+Business Media, LLC 2010

In this Special Issue of the Asia Pacific Journal of Management on Managing in Ethnic Chinese Communities, we seek to shed light on the complex and dynamic relationships existing in many ethnic Chinese businesses around the world. This is an exciting time to study ethnic Chinese business. Ethnic Chinese business used to mean Overseas Chinese firms, that is, enterprises run by Chinese business people based outside of Mainland China. That definition is no longer sufficient: successful ethnic Chinese businesses exist and are thriving all around Asia and increasingly, elsewhere (Ahlstrom \& Wang, 2010; Pan, 1990; Zeng \& Williamson, 2007). In particular, the rise of East Asian economies from Mainland China, Taiwan, to Southeast Asia has encouraged much study of how these economies (and their firms) grew so briskly while inspiring a model for economies in the developing world (Berger \& Hsiao, 1988; Carney, Gedajlovic, \& Yang, 2009; Fallows, 1995; Ramo, 2004; Seagrave, 1995).

The Asia Pacific Journal of Management would like to welcome a new Senior Editor, Xu Huang (Hong Kong Polytechnic University). Special thanks go to National Sun Yat-sen University (Kaohsiung, Taiwan), The Chinese University of Hong Kong, Texas Christian University, and Professors Garry Bruton and Mike Peng for their support of the current Special Issue. We would also like to thank the discussants for this Asia Pacific Journal of Management Special Issue Conference for their helpful and insightful comments. They are Michael Carney (Concordia University), Eric Gedajlovic (Simon Fraser University), Johngseok Bae (Korea University), Gong Yuanyuan (The Chinese University of Hong Kong), Michael N. Young (Hong Kong Baptist University), and Rico Lam (University of Macau).

D. Ahlstrom $(\bowtie)$

Department of Management, The Chinese University of Hong Kong, Shatin, NT, Hong Kong e-mail: ahlstrom@baf.msmail.cuhk.edu.hk

S.-j. Chen

National Sun Yat-sen University, Institution of Human Resource Management, Kaohsiung, Taiwan e-mail: schen@cm.nsysu.edu.tw

K. S. Yeh

Department of Business Management, National Sun Yat-sen University, Kaohsiung, Taiwan e-mail: kuangyeh@gmail.com 
Firms in ethnic Chinese communities have not only grown smartly in recent decades, but they are also becoming more important in the world's economy (Economist, 2010; Zeng \& Williamson, 2007). A hallmark of a market economy is also the vibrancy of its private entrepreneurship (Baumol, Litan, \& Shramm 2007). The economic growth and expansion of private enterprise in China and around East Asia is a testament to that view. China's economic miracle began back in the late 1970s when China liberalized its agricultural sector and quickly followed with the Household-responsibility system, which allowed people to set up small, private enterprises. During the first 15 years of reform in China, personal income growth outpaced GDP growth; the labor share of GDP rose and income distribution improved. ${ }^{1}$ Income growth has been more modest in recent years, though solid GDP growth has continued (Huang, 2010). Hong Kong experienced a similar economic takeoff starting in the $1960 \mathrm{~s}$, with economic growth sometimes exceeding $10 \%$ annually, bringing per capita GDP up to and beyond the levels of its (former) colonial governors in Great Britain (Maddison, 2006).

Other economies predominated by ethnic Chinese firms also experienced brisk growth in the latter part of the 20th century. Taiwan has generally enjoyed rapid economic expansion since the 1950s; the annual average rate of economic growth between 1952 and 1990 was a China-like 8.9\% annually (Maddison, 2006). Taiwan's economic development strategy originated in import substitution in the 1960s and quickly shifted to export-led policies as industry shifted towards high technology (e.g., semi-conductors and electronics). Taiwan is now the home of many of the world's largest makers of computers and associated hardware. Its firms produce about $50 \%$ of all chips, $70 \%$ of computer displays, and more than $90 \%$ of all portable computers. Taiwan has effectively upgraded its economy to a high technology workshop (Economist, 2010). Singapore and other countries in Southeast Asia, such as Malaysia and Indonesia, have similarly experienced substantial economic growth. This led to a very strong growth in per capita GDP in those countries, which made Singapore one of the wealthiest economies in the world, and correspondingly brought significant growth to Malaysia, Indonesia, and Thailand, much of which was spurred by ethnic Chinese firms in those countries (Ahlstrom, Nair, Young, \& Wang, 2006; Haley, Haley, \& Tan, 2009; Maddison, 2006).

\section{Firms in ethnic Chinese communities}

The fine economic performance of firms in ethnic Chinese communities around East Asia and the Pacific Rim has encouraged extensive inquiry on specific Asian business systems including what has come to be called Chinese capitalism or (more broadly) Asian capitalism (Ahlstrom \& Wang, 2010; Bond \& Hofstede, 1990; Carney et al., 2009; Hamilton, 2006; Redding, 1990; Whitley, 1992). Researchers have stressed the importance of Chinese culture in particular as a key explanation for the putatively unique business systems around East Asia, much in the way Max Weber's (1951) Protestant work ethic was used to explain economic growth in the

\footnotetext{
${ }^{1}$ Though Mainland China has seen some setbacks with respect to private sector reform (Huang, 2010), the signs are generally positive for continued economic growth.
} 
West (Ahlstrom \& Wang, 2010). Indeed, many of the economies that have developed the most rapidly over the past 50 years are Confucian-influenced East Asian ones, including those of Mainland China, Taiwan, Hong Kong, and several in Southeast Asia. Limited evidence does assert an association between (primarily Confucian) cultural values and economic growth over time in these economies (e.g., Bond \& Hofstede, 1990; Landes, 2000), though this viewpoint is not without controversy (Ahlstrom \& Wang, 2010; Ahlstrom, Young, Chan, \& Bruton, 2004; Pye, 2000; Singh, 2007; Studwell, 2007). That Confucian system is thought to include a harmonious and tolerant Chinese management style, thrift and self-sacrifice, loyalty to top management, and reciprocal loyalty to valued employees and suppliers. Similarly, Confucian traditions such as respect for elders, the importance of family, and the primacy of relationships are thought to influence structure and decisionmaking in firms in ethnic Chinese communities (Backman, 2001; Chen, 2001; Perkins, 2000).

At the strategic level, Confucianism places an emphasis on social capital and networking, which is of particular importance in a globalizing world (Chen, 2001; Haley et al., 2009). Firms run by Overseas Chinese often belong to large, loosely interconnected networks of firms (Claessens, Djankov, \& Lang, 2000; Kao, 1993) that prefer to conduct business with each other, sometimes with little formal contractual arrangement (Chen, 2001; Weidenbaum \& Hughes, 1996). These differences are heavily based on cultural traditions that seem to impact Chinese businesspeople irrespective of the country in which they live (Backman, 2001; Chen, 2001; Haley et al., 2009). This style of business is reportedly becoming more important in Mainland China where reforms have permitted the growth of private enterprise with similar organization to that of the Overseas Chinese. The management style of ethnic Chinese firms is thought by many to be a key mode of economic organization in East Asia not only because of its economic significance to local economies, but also because of its complex network organization and compatibility with the modern virtual organization (Ahlstrom et al., 2004; Haley et al., 2009).

Yet culture's role in the success of ethnic Chinese business is not entirely clear as culture can be (incorrectly) conflated with education systems, laws, and other more formal institutions and various traditions that may be more proximate contributors to entrepreneurial and economic development (Carney et al., 2009; Li \& Peng, 2008; Singh, 2007). For example, in the mid-20th century, social scientists argued that East Asia was not likely to become wealthy because Confucianism, Taoism, and related cultural factors limited consumer demand and thus hindered commercial development. But as the last several decades have seen significant economic growth in East Asia, the conclusions have changed. Many now argue that the success of Asia is culture-driven and based on Confucian culture's emphasis given to study, hard work, and harmonious relationships (e.g., Bond \& Hofstede, 1990; Landes, 1998; Mahathir, 1999). Yet how did this culturally-induced economic growth suddenly start happening without any major changes taking place in the culture of the region? If Asia's workforce is hard working, harmonious, and productive because of culture, it should have been that way in centuries past also. If culture was not causing growth in those economies in previous centuries, how did essentially the same culture suddenly start causing economic growth more recently? This point suggests that 
culture alone is not a direct cause of ethnic Chinese business success, though it may mediate performance through organization structure, formal institutions, or other variables. It is clear, however, that culture and other factors impacting ethnic Chinese organizations still need a great deal of study and clarification (Ahlstrom \& Wang, 2010; Li \& Peng, 2008).

Broadly speaking, it seems evident that the historical background and context of the region and its institutions are important in explaining managerial issues in ethnic Chinese firms (Tipton, 2009). However, although research that addresses historical context (Zald, 1996) is beneficial to theory development, ethnic Chinese business is a complex phenomenon that cannot simply be attributed to culture or some other latent variable (Li \& Peng, 2008; Singh, 2007) or just summarized in terms of cost innovation (Zeng \& Williamson, 2007). Ethnic Chinese business is not a homogeneous group of organizations. There are a variety of institutions and contexts (broadly defined as historical, cultural, path-dependent, etc.) that can impact industrial systems and cause a lot of variety-even in a seemingly homogeneous place such as East Asia.

The papers in this Special Issue are generally supportive of this perspective. Researchers need to look past simple cultural variables and characteristics to the varieties of factors which influence the success of ethnic Chinese communities (Fang, 2010). Culture is important in the study of ethnic Chinese firms, yet so are other aspects of management, namely institutions and context, which are the subject of several studies in this Special Issue. In addition, aspects of Chinese culture may actually hinder firm development, such as an over-reliance on guanxi as opposed to formal contracting, or cultural challenges related to entrepreneurship and innovation (Backman, 2001; Studwell, 2007; Wang, Ahlstrom, Nair, \& Hang, 2008), a topic that is also taken up in this issue ( $\mathrm{Lin} \& \mathrm{Si}, 2010$ ). Given the importance of institutions and the variety of contexts facing today's firms, significant empirical diversity in industrial regimes can result, including within the world of ethnic Chinese business (Carney et al., 2009). These and other conceptual and empirical challenges are taken up in this Special Issue on Managing in Ethnic Chinese Communities.

\section{The papers in this Special Issue}

We received a total of 38 submissions for this Special Issue in 2008. After the first round of reviews, 18 authors were invited to present their papers at the Special Issue Conference hosted by National Sun Yat-sen University, Taiwan on December 12 and 13, 2008. The College of Management at National Sun Yat-sen University is one of the leading business schools in Taiwan and is the first university to host the Special Issue Conference for APJM in Taiwan. More than 80 attendees, including guest editors, authors, invited commentators, keynote speakers, $\mathrm{PhD}$ and Masters students, and other interested scholars participated in the Special Issue Conference. We invited two keynote speakers: Professor David Lamond, Editor-in-Chief of the Journal of Management History and Professor David Ahlstrom, then Senior Editor, now Editorin-Chief of the Asia Pacific Journal of Management to talk about APJM and publishing in international journals. In addition, Professor Garry Bruton, President of the Asia Academy of Management and Editor-in-Chief of the Academy of 
Management Perspectives, also attended the conference and addressed the participants.

The 18 papers presented at the Special Issue Conference were invited to revise and resubmit in the second round; however, some were dropped due to unsuccessful fulfillment of the review process (though some of those papers did go through subsequent revision for a regular $A P J M$ issue). In total, eleven papers were accepted and published in this Special Issue, along with this introductory article. These papers can be categorized into two groups - conceptual (5 papers) and empirical (6 papers)and are summarized in Table 1.

\section{Conceptual papers}

In their perspectives paper, Zhou and Peng (2010) ask the question of how firms make strategic choices in response to institutional transitions. Previous research was not always clear about the conditions under which such strategic transitions would occur and how this might impact strategic choice. They develop a model to predict that such transitions are contingent upon the multiple facets of a country's institutional profile, including informal institutions such as national culture and formal institutions that encourage market competition. Their model also suggests that industry- and firm-level contingencies would affect these strategic transitions.

Two subsequent papers examine some unusual aspects of Chinese society. In this Special Issue's Commentary paper, Lin and Si (2010) delineate an exceptional type of network-based social capital in China - dense strong-ties versus sparse weak-ties - to address a paradox of substantial social capital during its economic transition towards a market system in the past decades. They investigate how the social capital system in China was formed under conditions of resource scarcity and upheaval during China's chaotic 20th century, and then how Chinese social capital led to certain unfavorable societal and organizational consequences. Lin and Si (2010) also raise the possibility that guanxi may cause problems for a firm because of the reciprocal obligations that may come along with it and discuss those problems. Research has regularly assumed that guanxi was always good to have whereas Lin and Si (2010) suggest connections may also carry unwanted obligations and create problems for a firm and the economy.

Fuller (2010), in a provocative paper on the technology sector in China, identifies three distinct patterns of investment behavior by venture capital firms in technology start-ups in China. First, the service-oriented, light-technology investment behavior of foreign firms (Bhide, 2008) is seldom found among ethnic Chinese firms. Second, the technology-creation investment behavior of the foreign firms is embedded in ethnic Chinese firms. Third, local state-funded Chinese venture capital firms choose either to invest in state-directed projects or typically opt out of investing in technology start-ups entirely. Fuller (2010) finds that the different legal environments are the critical factor in explaining the differences in investment behavior between the strictly foreign and the ethnic Chinese-embedded foreign firms. In addition, the political factors which influence the distribution of finance play important roles in explaining the behavior and failure of the local state-run venture capital firms. 
Table 1 Topics and main arguments and findings of papers included in this Special Issue.

Authors Topic/Study Areas Main arguments and findings

Conceptual Papers

Zhou \& Peng Perspectives: Institutional transitions (2010) and strategic choices

Lin \& Si Commentary: Social capital in China (2010)

Fuller (2010) Venture capital in China

Tang (2010) Entrepreneurs in China

Dieleman Corporate strategy in Indonesian

(2010) Chinese groups

\section{Empirical Papers}

Zheng \& Organizational turnover in six Asian Lamond countries
The authors ask the question of how firms make strategic choices in response to institutional transitions so as to fill the research gap regarding the conditions under which such strategic transitions would occur. They develop a model to predict that such transitions are contingent upon the multiple facets of a country's institutional profile, including informal institutions such as national culture and formal institutions that encourage market competition.

The authors utilize a new approach, including strength of social ties and density of network, to extend current literature on social tie research in the Chinese context. They find that the role and functions of the Chinese government are significantly related to the variety of social capital. They argue that guanxi or connections are not always beneficial to an organization but can also be a burden to a firm.

Three distinct patterns of venture capital investment behavior in technology sector startups in China are identified. He finds that the different investment behaviors can be explained by differing legal environments. In addition, political factors of influencing finance distribution can help to explain the failure of the start-up venture capital.

By employing institutional theory and an entrepreneurial framework, the author finds that human capital, social capital, and social skill all contribute to the very important step of opportunity recognition among entrepreneurs.

Through an in-depth studies of ethnic Chinese firms in Indonesia, the author provides an alternative notion of shock imprinting, which tends to be more defensive when corporations face external shocks. Shock-imprinting is different from the traditional strategy of active adaptation. The information provided on Chinese-owned Indonesian firms is more nuanced and in-depth than was much previously available.

Through a large sample of 529 multinational enterprises, the authors find that training, size, the length of operation in local market, and industry show significant effects on employee turnover measured at the organizational level. This is particularly important given the problems with employee turnover and the difficulty of retaining good managers in East Asia. 
Table 1 (continued).

\begin{tabular}{lll}
\hline Authors & Topic/Study Areas & Main arguments and findings \\
\hline $\begin{array}{l}\text { Wu \& } \\
\text { Pangarkar }\end{array}$ & Competitive density in China & $\begin{array}{l}\text { By using a survey of 1,500 Chinese firms, the } \\
\text { authors find that collaboration reduces perceived } \\
\text { competitive intensity because of the twin } \\
\text { mechanisms of information acquisition and risk } \\
\text { reduction. Their analysis provides a very strong } \\
\text { support to the bidirectional argument. }\end{array}$
\end{tabular}

Chen \& $\quad$ Mergers and acquisitions in China Young

The study, using a cross border M\&A secondary (2010) dataset, investigates that the mergers and acquisitions by the Chinese government are typically not in the best interests of the minority shareholders, consistent with the principalprincipal perspective. The authors find that increased government ownership in the acquiring firm is associated with investors viewing a crossborder merger deal in less favorable terms. They thus find a negative moderating effect of environmental complexity on the relationship between the Chinese government ownership and investor perceptions of a CBMA deal.

Tung \& Diaspora and trade facilitation in By using a sample of 135 Australian firms Chung Australian firms in China, Hong Kong, (2010) and Taiwan operating in Greater China, the authors find that companies owned by immigrants who are also in key decision-making positions are more likely to have a higher resource commitment to their firm.

Zou, Chen, New venture growth in China By adopting the resource-based view, the study investigates the antecedents and consequences of high-tech new venture growth strategy, which is subsequently tested with 252 firms using firmlevel survey data. They find that technological and marketing capabilities, strong/weak network ties, and financial resources all exert effects on new venture growth strategies.

Lai, Lam, \& Employee supplication behavior in The authors examine how employee supplication Liu (2010) China impact job performance by using 158 supervisorsubordinate dyads in china. They find that female and junior employees do not receive negative job performance ratings due to supplication and can benefit from it.

The final two conceptual papers are related to entrepreneurship and corporate strategy in turbulent environments. Tang (2010), drawing on her extensive research on opportunity recognition in entrepreneurship, investigates how entrepreneurs collect information and knowledge in seeking opportunities when they face a relatively weak infrastructure and institutional regime as in China. Based on institutional theory and an integrative framework of entrepreneurship, she develops a model of incorporating both individual and environmental effects. The individual characteristics include human capital, social capital, and social skills. Tang further proposes that the relationships between individual characteristics and opportunity recognition are dependent on the entrepreneurial environment and related turbulence. 
Dieleman (2010) as part of her extended research program on the large ethnic Chinese conglomerates of Southeast Asia, examines the effect of external shocks on corporate strategy on a set of cases in Indonesia. Her study reports an in-depth, longitudinal, and comparative case study of four prominent ethnic Chinese business groups in Indonesia. The firms studied sought to implement major strategic changes in response to serious problems emerging during the Asian financial crisis of 19971998. Previous theories put emphases on strategic continuity and adaptation, which were only partially able to explain the results. She offers the alternative notion of "shock-imprinting" to explain the result. Shock-imprinting suggests that companies continue to use defensive strategies after the external shock, following almost a threat rigidity mode of response. Dieleman's study is one of the first in-depth case studies of ethnic Chinese business groups in Indonesia and should form the basis for a better understanding of the unusual organizational form present among the familyowned conglomerates of East Asia (c.f. Haley et al., 2009).

\section{Empirical papers}

The following empirical papers in this Special Issue are broadly related to turnover issues in human resources. Zheng and Lamond (2010) examine the determinants of employee turnover at the organizational level for a large sample of multinational companies (MNCs) in Asia. They collect data from 529 MNCs in six Asian countries and test the effects of a group of organizational variables, including training, size, age, industry, percentage of expatriate managers, and headquarters' national bases on organizational turnover. The results show that training, size, the length of operation in local subsidiary, and nature of industry exerted significant impacts on organizational turnover. This study contributes to better understanding of employee turnover at the firm level and implications to MNCs in the Greater Chinese region and Asia.

Regarding competition and collaboration, Wu and Pangarkar (2010) test a bidirectional relationship between perceived competitive intensity of firm and its strategic response to forge collaboration by using a large sample of 1,500 Chinese firms. Based on the theoretical perspectives of enactment, cognition, and the resource-based view of the firm, they hypothesize that collaboration reduced the perceived competitive intensity due to the twin mechanisms of information acquisition and risk reduction. An inverted U-shaped relationship for the impact of perceived competitive intensity on the probability of forming collaboration is suggested.

In their paper on cross-border merger and acquisition in China, Chen and Young (2010) argue that, in most of the high-profile cross-border M\&As, the Chinese government is the largest shareholder of the acquiring firms. Therefore, the Chinese government pushes these deals even though they may not be in the best interests of minority shareholders. This is consistent with the principal-principal conflict as discussed by Michael Young and colleagues in his work on corporate governance in Asia (e.g., Young, Peng, Ahlstrom, Bruton, \& Jiang, 2008). In the current paper, Chen and Young (2010) examine the relationship between increased government ownership and investors viewing a cross-border merger deal in less favorable terms, 
and find support for investor skepticism of cross-border mergers and acquisitions deals when the Chinese government is the majority owner. When testing the moderating effects of environmental complexity in the relationship, Chen and Young were not able to find support for an environmental complexity effect.

One empirical paper investigates issues related to market entry and expansion. In one of the first papers on this topic and research site, Rosalie Tung and Henry Chung (2010) examine whether members of an ethnic diaspora such as the Overseas Chinese can facilitate trade between their adopted country (in this case, Australia) and their country of ethnic origin. By using a distinctive sample of 135 firms from Australia that are also operating in Greater China (Mainland China, Hong Kong, and Taiwan), they find that companies that are owned by immigrants or have hired immigrants for key decision-making positions are more likely to resort to a higher resource commitment when entering into the target market. This research further clarifies the need for boundary conditions when examining Chinese business.

Zou, Chen, and Ghauri (2010) adopt the resource-based view to investigate the antecedents and consequences of new venture growth strategy in China. In another paper on high-tech ventures, they collect 252 questionnaires from Chinese new ventures in that sector and identify three generic growth patterns of Chinese hightech new ventures - organic growth, partnership growth, and acquisition growth. They find that technological capabilities, network ties, marketing capabilities, and financial resources are found to have different effects on new venture growth strategies. Moreover, they find different venture growth strategies show varying impacts on performance as measured by survival, competitive advantages, and profits. China continues to struggle in developing an indigenous high-technology sector, and papers such as this from Professor Pervez Ghauri and his colleagues contribute to our understanding of that important sector and potential barriers to growth and innovation (Wang et al., 2008).

Finally, Rico Lam and colleagues (Lai, Lam, \& Liu, 2010) examine how employee supplication, or making oneself vulnerable to a boss or decision-maker, impacts employee job performance. They use 158 supervisor-subordinate dyads in China to test hypotheses related to supplication. They find that female and junior employees do not receive negative job performance ratings due to supplication and can benefit from it. Age, however does not moderate the supplication-performance relationship. Their findings are consistent with the social norms in Confucianism regarding the modest role of certain social classes in enhancing social harmony. These results contribute to theory on impression management in which supplication is a relatively unexplored impression management tactic.

\section{Discussion: Whither the Chinese context?}

The study by Lai and colleagues (2010) and several others in this Special Issue also illustrate why it is important to study indigenous firms (and their members) in context. New concepts may emerge and constructs can be developed that would be easy to overlook in another research site. Supplication is a good example of this. It is an employee behavior that has not received that much attention in management research in the West. Western society tends to value self-esteem highly, whether or 
not it is earned or developed (Locke, 2006). Supplication differs considerably from esteem-building or promotional techniques and would tend to get overlooked as an influence strategy in a Western context, but it has much relevance as an indigenous construct in a Chinese context. And as Lai and colleagues (2010) argue, supplication is a construct that can be validated and applied in East Asian research settings and subsequently tested in the West. This is in part what is meant by Tsui and Lau (2002) when they write of the importance of indigenous research and what it can contribute to the study of organizations in a variety of settings.

The papers in this Special Issue hope to contribute further indigenous research and the testing and extension of theory in the important context of ethnic Chinese firms. Yet much more research is needed to build a better understanding of this important and growing industrial sector of the world's economy. In particular, future research on ethnic Chinese business should seek to address three main concerns. The first concerns the better specification of the context of ethnic Chinese business. The Chinese context includes both a specific set of institutional arrangements and a set of cultural understandings, both embedded in the distinct history of Chinese and Overseas Chinese societies (Ahlstrom \& Wang, 2010; Haley et al., 2009). The institutional arrangements involve the state, its laws, economic system, and political organization, and the more formal aspects of the societies of Greater China and Southeast Asia. The cultural understandings include the values, beliefs, scripts, and practices that are associated with Chinese culture and Chinese business and how it is modified in interaction with cultures outside of China (Li, Schulze \& Li, 2009; Studwell, 2007). Understanding these institutional and cultural arrangements in their contemporary and regional manifestations (Ahlstrom \& Wang, 2010) are essential to comprehending ethnic Chinese organizations, and how these firms (and those doing business with them) can function more effectively (Hitt, Ahlstrom, Dacin, Levitas, \& Svobodina, 2004). At the same time, such research can also help to identify largely indigenous constructs that may be overlooked outside of the Chinese context, as noted with the supplication paper in this issue.

Second, well-established constructs developed and tested primarily in an AngloAmerican-based setting can be investigated in a Chinese environment to see how the constructs hold up in a significantly different setting and how they may require some different implementation approaches. Such research would also help to suggest how different conditions may affect something well understood such as goal setting and performance (Locke \& Latham, 2009) or social influence (Wosinska, Cialdini, Barrett, \& Reykowski, 2001). A theory such as goal setting may be quite valid in the Chinese setting, but may require different implementation to realize the desired performance outcome (Tsui \& Lau, 2002). For example, it was once thought that goal-based pay for performance systems would not be accepted in China because of the social legacy of level pay and the collective nature of the culture. Yet firms have been able to implement both individual- and team-based incentive pay through social influence practices, even in cultures where such schemes were thought to be difficult to implement (Cialdini, 2006). One firm overcame resistance to goal setting and performance-based pay by convincing a couple of opinion leaders in the firm to participate in the incentive program. When the other employees saw how well they were doing, they started to opt into the program. Within about 2 years, the whole factory adopted the new scheme. It took a little more effort, but the performance 
incentive system was eventually accepted, even in an institutional and cultural setting that by all rights should have rejected it. The implementation - in this case, additional social influence steps - is what changed in the Chinese setting, not the goal setting and pay for performance system.

Finally, additional study in the Chinese commercial context would also be also crucial to the identification and elaboration of context-free constructs and managerial techniques that can function everywhere. While conceding the importance of context, most students of organizations aspire to a more general understanding of organizations and human behavior. Social influence provides another good example. Research in social psychology suggests that there are six main principles of influence, and as they are based on cognition and biopsychology, they are likely to be universal (Cialdini, 2006).

This contention of universality has been tested in settings around the world. Much research has shown that in the case of social influence, the commonly understood principles of influence do work in a variety of cultural settings (Wosinska et al., 2001), though certain influence principles may be more effective (Morris, Podolny, \& Ariel, 2001) or preferred (Fu \& Yukl, 2000) than others. For example, in China, the power of upward appeals to someone's boss or another authority to sway that person to a course of action was a preferred method of influence, compared to that of similar samples in the United States or Europe that preferred a reciprocal relationship or the adherence to written rules as the main influence activator (Fu \& Yukl, 2000; Morris et al., 2001).

Such research helps to affirm the universality of the main principles of influence, but also shows how different principles may hold primacy in different cultures, such as with the particular importance given to expertise and authority in China (Morris et al., 2001). It would also serve to clarify the construct of guanxi which is often incorrectly referred to as a "concept unique to China." More than 50 years of research in social psychology from Alvin Gouldner (1960) to Robert Cialdini (Cialdini, 2006; Goldstein, Martin, \& Cialdini, 2009) shows this statement about the uniqueness of guanxi to China to be categorically incorrect (c.f. Peng \& Heath, 1996). Research in the Chinese context helps distinguish ideas and constructs that are universal and largely context free, from those that require conditions or differing implementation to operate, or from still others that seem to be unique to China, but are not. The development and improvement of management theory can be facilitated through research on this important and populous research site. Research on ethnic Chinese business is no longer just for China business researchers, but can now inform general management research as well as helping to demystify managing in ethnic Chinese communities.

\section{References}

Ahlstrom, D., Nair, A., Young, M. N., \& Wang, L. C. 2006. China: Competitive myths and realities. SAM Advanced Management Journal, 71(3): 4-10.

Ahlstrom, D., \& Wang, L. C. 2010. Entrepreneurial capitalism in East Asia: How history matters. In H. Landström \& F. Lohrke (Eds.). Historical foundations of entrepreneurial research: 819-879. Cheltenham, UK: Edward Elgar. 
Ahlstrom, D., Young, M. N., Chan, E. S., \& Bruton, G. D. 2004. Facing constraints to growth? Overseas Chinese entrepreneurs and traditional business practices in East Asia. Asia Pacific Journal of Management, 21(3): 263-285.

Backman, M. 2001. Asian eclipse: Exposing the dark side of business in Asia, Revised ed. Singapore: Wiley.

Baumol, W. J., Litan, R. E., \& Schramm, C. J. 2007. Good capitalism, bad capitalism. New Haven, CT: Yale University Press.

Berger, P. L., \& Hsiao, H. M. 1988. In search of an East Asian developmental model. New Brunswick, NJ: Transaction.

Bhide, A. 2008. The venturesome economy: How innovation sustains prosperity in a more connected world. Princeton, NJ: Princeton University Press.

Bond, M. H., \& Hofstede, G. 1990. The cash value of Confucian values. In S. R. Clegg \& S. G. Redding (Eds.). Capitalism in contrasting cultures: 383-390. New York: Walter de Gruyter.

Carney, M., Gedajlovic, E., \& Yang, X. 2009. Varieties of Asian capitalism: Toward an institutional theory of Asian enterprise. Asia Pacific Journal of Management, 26(3): 361-380.

Chen, M.-J. 2001. Inside Chinese business: A guide for managers worldwide. Boston: Harvard Business School Publishing.

Chen, Y. Y., \& Young, M. N. 2010. Cross-border mergers and acquisitions by Chinese listed companies: A principal-principal perspective. Asia Pacific Journal of Management, 27 (this issue).

Cialdini, R. B. 2006. Influence: The psychology of persuasion, Revised ed. New York: Harper Paperbacks.

Claessens, S., Djankov, S., \& Lang, L. 2000. The separation of ownership and control in East Asian corporations. Journal of Financial Economics, 58: 81-112.

Dieleman, M. 2010. Shock-imprinting: External shocks and ethnic Chinese business groups in Indonesia. Asia Pacific Journal of Management, 27 (this issue).

Economist. 2010. Hybrid vigour: Taiwan's tech firms are conquering the world-and turning Chinese. May, 29: 68-69.

Fallows, J. 1995. Looking at the sun: The rise of the new East Asian economic and political systems. New York: Vintage.

Fang, T. 2010. Asian management research needs more self-confidence: Reflection on Hofstede (2007) and beyond. Asia Pacific Journal of Management, 27(1): 155-170.

Fu, P. P., \& Yukl, G. 2000. Perceived effectiveness of influence tactics in the United States and China. Leadership Quarterly, 11(2): 251-266.

Fuller, D. B. 2010. How law, politics and transnational networks affect technology entrepreneurship: Explaining divergent venture capital investing strategies in China. Asia Pacific Journal of Management, 27 (this issue).

Goldstein, N. J., Martin, S. J., \& Cialdini, R. B. 2009. Yes!: 50 scientifically proven ways to be persuasive. New York: Free.

Gouldner, A. 1960. The norm of reciprocity: A preliminary statement. American Sociological Review, 25 (2): 161-178.

Haley, G. T., Haley, U. C. V., \& Tan, C. T. 2009. New Asian emperors: The business strategies of the Overseas Chinese. New York: Wiley.

Hamilton, G. G. 2006. Commerce and capitalism in Chinese societies. London: Routledge.

Hitt, M. A., Ahlstrom, D., Dacin, M. T., Levitas, E., \& Svobodina, L. 2004. The institutional effects on strategic alliance partner selection in transition economies: China vs. Russia. Organization Science, 15(2): 173-185.

Huang, Y. 2010. Debating China's economic growth: The Beijing consensus or the Washington consensus?. Academy of Management Perspectives, 24(2): 31-47.

Kao, J. 1993. The worldwide web of Chinese business. Harvard Business Review, 71(2): 24-36.

Lai, J. Y. M., Lam, L. W., \& Liu, Y. 2010. Do you really need help? A study of employee supplication and job performance in China. Asia Pacific Journal of Management, 27 (this issue).

Landes, D. 1998. The wealth and poverty of nations: Why some are so rich and some so poor. New York: W. W. Norton.

Landes, D. 2000. Culture makes almost all the difference. In L. E. Harrison \& S. P. Huntington (Eds.). Culture matters: How human values shape human progress: 2-13. New York: Basic Books.

Li, S., Schulze, W. \& Li, Z. 2009. Plunging into the sea, again? A study of serial entrepreneurship in China. Asia Pacific Journal of Management, 26(4): 667-680.

Li, Y., \& Peng, M. W. 2008. Developing theory from strategic management research in China. Asia Pacific Journal of Management, 25(3): 563-572.

Lin, J., \& Si, S. X. 2010. Can guanxi be a problem? Contexts, ties, and some unfavorable consequences of social capital in China. Asia Pacific Journal of Management, 27 (this issue). 
Locke, E. A. 2006. The educational, psychological, and philosophical assault on self-esteem. The Objective Standard, 1(4): 65-82.

Locke, E. A., \& Latham, G. P. 2009. Has goal setting gone wild, or have its attackers abandoned good scholarship?. Academy of Management Perspectives, 23(1): 17-23.

Maddison, A. 2006. The world economy, vol. 1: A millennial perspective, vol. 2: Historical statistics. Paris: OECD.

Mahathir, M. 1999. A new deal for Asia. Kuala Lumpur: Pelanduk.

Morris, M. W., Podolny, J. M., \& Ariel, S. 2001. Culture, norms, and obligations: Cross-national differences in patterns of interpersonal norms and felt obligations toward coworkers. In W. Wosinska, R. B. Cialdini, D. W. Barrett \& J. Reykowski (Eds.). The practice of social influence in multiple cultures: 84-107. Mahwah, NJ: Lawrence Erlbaum Associates.

Pan, L. 1990. Sons of the Yellow Emperor: The story of the overseas Chinese. London: Mandarin.

Peng, M. W., \& Heath, P. S. 1996. The growth of the firm in planned economies in transition: Institutions, organizations, and strategic choice. Academy of Management Review, 21: 492-528.

Perkins, D. 2000. Law, family ties and the East Asian way of business. In L. E. Harrison \& S. P. Huntington (Eds.). Culture matters: How human values shape human progress: 232-244. New York: Basic Books.

Pye, L. W. 2000. Asian values: From dynamos to dominoes. In L. E. Harrison \& S. P. Huntington (Eds.). Culture matters: How human values shape human progress: 244-255. New York: Basic Books.

Ramo, J. C. 2004. The Beijing consensus: Notes on the new physics of Chinese power. London: The Foreign Policy Centre.

Redding, S. G. 1990. The spirit of Chinese capitalism. New York: Walter de Gruyter.

Seagrave, S. 1995. Lords of the rim: The invisible empire of the overseas Chinese. London: Bantam Books.

Singh, K. S. 2007. The limited relevance of culture to strategy. Asia Pacific Journal of Management, 24 (4): 421-428.

Studwell, J. 2007. Asian godfathers: Money and power in Hong Kong and Southeast Asia. London: Profile Books.

Tang, J. 2010. How entrepreneurs discover opportunities in China: An institutional view. Asia Pacific Journal of Management, 27 (this issue).

Tipton, F. B. 2009. Southeast Asian capitalism: History, institutions, states, and firms. Asia Pacific Journal of Management, 26(3): 401-434.

Tsui, A. S., \& Lau, C. M. 2002. Research on the management of enterprises in the People's Republic of China: Current status and future directions. In A. S. Tsui \& C. M. Lau (Eds.). Management of enterprises in the People's Republic of China: 1-27. New York: Kluwer Academic.

Tung, R. L., \& Chung, H. F. L. 2010. Diaspora and trade facilitation: The case of ethnic Chinese in Australia. Asia Pacific Journal of Management, 27 (this issue).

Wang, L. C., Ahlstrom, D., Nair, A., \& Hang, R. Z. 2008. Creating globally competitive and innovative products: China's next Olympic challenge. SAM Advanced Management Journal, 73(3): 4-14.

Weber, M. 1951. The religion of China: Confucianism and Taoism. New York: Free.

Weidenbaum, M., \& Hughes, S. 1996. The bamboo network: How expatriate entrepreneurs are creating new superpower in Asia. New York: Free.

Whitley, R. 1992. Business systems in East Asia: Firms, markets and societies. London: Sage.

Wosinska, W., Cialdini, R. B., Barrett, D. W., \& Reykowski, J. (Eds.). 2001. The practice of social influence in multiple cultures. Mahwah, NJ: Lawrence Erlbaum Associates.

Wu, J., \& Pangarkar, N. 2010. The bidirectional relationships between competitive intensity and collaboration: Evidence from China. Asia Pacific Journal of Management, 27 (this issue).

Young, M. N., Peng, M. W., Ahlstrom, D., Bruton, G. D., \& Jiang, Y. 2008. Corporate governance in emerging economies: A review of the principal-principal perspective. Journal of Management Studies, 45(1): 196-220.

Zald, M. N. 1996. More fragmentation? Unfinished business in linking the social sciences and the humanities. Administrative Science Quarterly, 41(2): 251-261.

Zeng, M., \& Williamson, P. J. 2007. Dragons at your door: How Chinese cost innovation is disrupting global competition. Boston: Harvard Business School Publishing.

Zheng, C., \& Lamond, D. 2010. Organizational determinants of employee turnover for multinational companies in Asia. Asia Pacific Journal of Management, 27 (this issue).

Zhou, J. Q., \& Peng, M. W. 2010. Relational exchanges versus arm's-length transactions during institutional transitions. Asia Pacific Journal of Management, 27 (this issue).

Zou, H., Chen, X., \& Ghauri, P. 2010. Antecedents and consequences of new venture growth strategy: An empirical study in China. Asia Pacific Journal of Management, 27 (this issue). 
David Ahlstrom ( $\mathrm{PhD}$, New York University) is a professor at The Chinese University of Hong Kong. He obtained his PhD in management and international business from NYU in 1996, after having spent several years in start-up firms. His research interests include management in Asia, entrepreneurship, and management and organizational history. He has published over 60 peer-reviewed articles in journals such as the Strategic Management Journal, Academy of Management Review, Journal of International Business Studies, Journal of Business Venturing, and Asia Pacific Journal of Management. He also co-authored the textbook International Management: Strategy and Culture in the Emerging World. He has served on the editorial boards of the Journal of International Business Studies and Journal of Small Business Management in addition to APJM. Professor Ahlstrom has guest edited two Special Issues of Entrepreneurship: Theory \& Practice. He has also guest edited two Special Issues of APJM (Turnaround in Asia in 2004 and Managing in Ethnic Chinese Communities in 2010, this issue), and served as a Senior Editor during 2007-2009. Professor Ahlstrom became Editor-in-Chief of the Asia Pacific Journal of Management in 2010.

Shyh-jer Chen (PhD, University of Illinois at Urbana-Champaign) is a professor in the Institute of Human Resource Management at National Sun Yat-sen University, Taiwan. He received his PhD from the School of Labor and Employment Relations from Urbana-Champaign. His research interests include strategic and international human resource management and industrial relations. His research has been published in the Journal of International Business Studies, Human Resource Management, Industrial Relations, Family Business Review, and International Journal of Human Resource Management, as well as several Chinese language journals. Professor Chen is the former Editor-in-Chief of Organization and Management, which is the official journal of Taiwan Academy of Management and is sponsored by Taiwan's National Science Council.

Kuang S. Yeh ( $\mathrm{PhD}$, Carnegie Mellon University) is a professor in the Department of Business Management at National Sun Yat-sen University, Taiwan. His research interests are in family business and entrepreneurship, governance structures in Taiwan's high tech industry, and organization growth and change in Mainland China's private enterprises. He is the author of eight well-recognized general management textbooks (in Chinese) and more than 50 academic articles. His research has been published in journals such as the Harvard Business Review, American Journal of Sociology, Journal of World Business, Asia Pacific Journal of Management, International Business Review, and several Chinese language journals in management and the social sciences. Professor Yeh also currently serves as the Deputy Minister of the Ministry of Transportation and Communications of Taiwan. 